\title{
A Psychology of Power That is Embedded in Societal Structures
}

\author{
Michael W. Kraus and Brittany Torrez \\ Yale University, School of Management
}

\begin{abstract}
Correspondence concerning this article should be addressed to Michael W. Kraus or Brittany Torrez at Yale University, School of Management, Evans Hall, 165 Whitney Ave., New Haven, CT, 06511. Email: michael.kraus@yale.edu, brittany.torrez@yale.edu
\end{abstract}




\begin{abstract}
Here, we look ahead to a psychology of power that is embedded in societal structures, specifically with regard to the North American context of race, gender, and social class. We argue that studies of power are limited when decoupled from these societal structures of power and we make this argument by examining dominant working definitions and links between power and prosociality. We end with a suggestion that a fully embedded and historical psychological account of social power will require greater constraints on generality, additional descriptive work on the experience of power in everyday life, and methods and samples that bring research on social power out of university spaces and into the places, spaces, and institutions where that power is intertwined. (120 words)
\end{abstract}




\section{A Psychology of Power That is Embedded in Societal Structures}

In the psychological study of social power, researchers often ask participants to try to imagine a time in which they "had power over another individual or individuals" (1-3). An often used methodology for eliciting the psychological state of having power, this exercise is complicated by the existence of persistent societal power structures: In the context of one's experience in communities of scarce resources - where the experience of power over others is embedded in control of economic capital to which these communities have been historically denied access — can a person truly recall an experience where they "controlled the ability of another person or persons to get something they wanted?” (1). This example raises the possibility that some participants experience a kind of power, one based on controlling others, for the very first time in the context of imagining it in one of these experiments.

Here we argue that the experience of psychological power is necessarily defined by societal structures that manifest, in the North American context, as hierarchies that include race, gender, and social class $\left(4-7,8^{* *}, 9\right)$. Understanding psychological power through the lens of societal power structures elicits reinterpretations of the very definition and uses of social power that broaden the construct beyond simply controlling the outcomes experienced by other people. This embedded perspective also highlights a handful of recommendations for a fully contextualized and historical psychological science of power for the $21^{\text {st }}$ century-one that has more constraints on generality, additional descriptive analyses of experiences of power, and a renewed focus on bringing power out of narrow conceptions of personal control to social movements and community organizing around societal power structures.

\subsection{Misunderstandings of Power: Seeking Power}


The central purpose of this review is to highlight the disconnect between a study of social power that assesses power as a trait based variable (10) or manipulates power based on subtle social reorganizations where participants imagine or experience a time they had (lacked) power (11), and the prevailing power structures (e.g., race, gender, social class) that ripple through many social situations and institutions in society throughout history $\left(4,8^{* *}, 12,13,14^{* *}\right)$. We contend that these prevailing structures shape how you define power, who has access to it, whether people seek it, and how we understand the ways in which power shapes society.

One of the assertions of research on psychological power is, though having it shapes some of the ways in which people misperceive the world and stereotype others (15-17), that power holds many benefits to individuals including greater control over resources (18), longevity (19-20), happiness and positive affect (21), and more abstract thought (2-3, 22). This assertion, that power benefits individual recipients of it, is based in part on an assumption that individuals see power as a positive driving force in society’s organization and operation $\left(23^{*}, 24\right)$.

An alternative account of power that is embedded in sociohistorical power structures casts the construct in slightly different terms: Principally as a valued resource used by traditionally high status groups $(8,25-26)$ and often martialed as coercion and oppression of low status groups (27-28). In this light, it is clearer why individuals from lower status groups in society avoid this kind of personal power in the context of their work lives (29*, 30*), why organizations erect barriers to achieving power, via discrimination and bias, for people from these groups (31-34), why subordinates react with heightened hostility to the power of individuals from groups that traditionally lack this sort of power (35**, 36), and this alternative account of power likely contributes to the reduced mobility of lower status groups in society, particularly people of color $(29,37)$. 
Largely missing from some psychological studies of power (e.g., 38), is a conceptualization of the construct that are based in collaborations within communities of people struggling to upend larger systems of inequality. It is this sort of collective power that lower status groups in society prefer $\left(30^{*}\right)$, and it is collective power, normally organized through labor unions, that is both most effective historically in reducing economic inequalities borne from labor practices (39-40), and most in decline in the US (Figure 1). A psychological study of power that includes its more collective forms and functions would advance our understanding of individual power's relationship to structures of power. The psychological focus on personalized power promotes only a partial understanding of the construct that might diminish people's tendency to think of organizing as central to resisting societal power structures, and ironically, promote blame of traditionally low status groups for their lack of economic advancement (41).

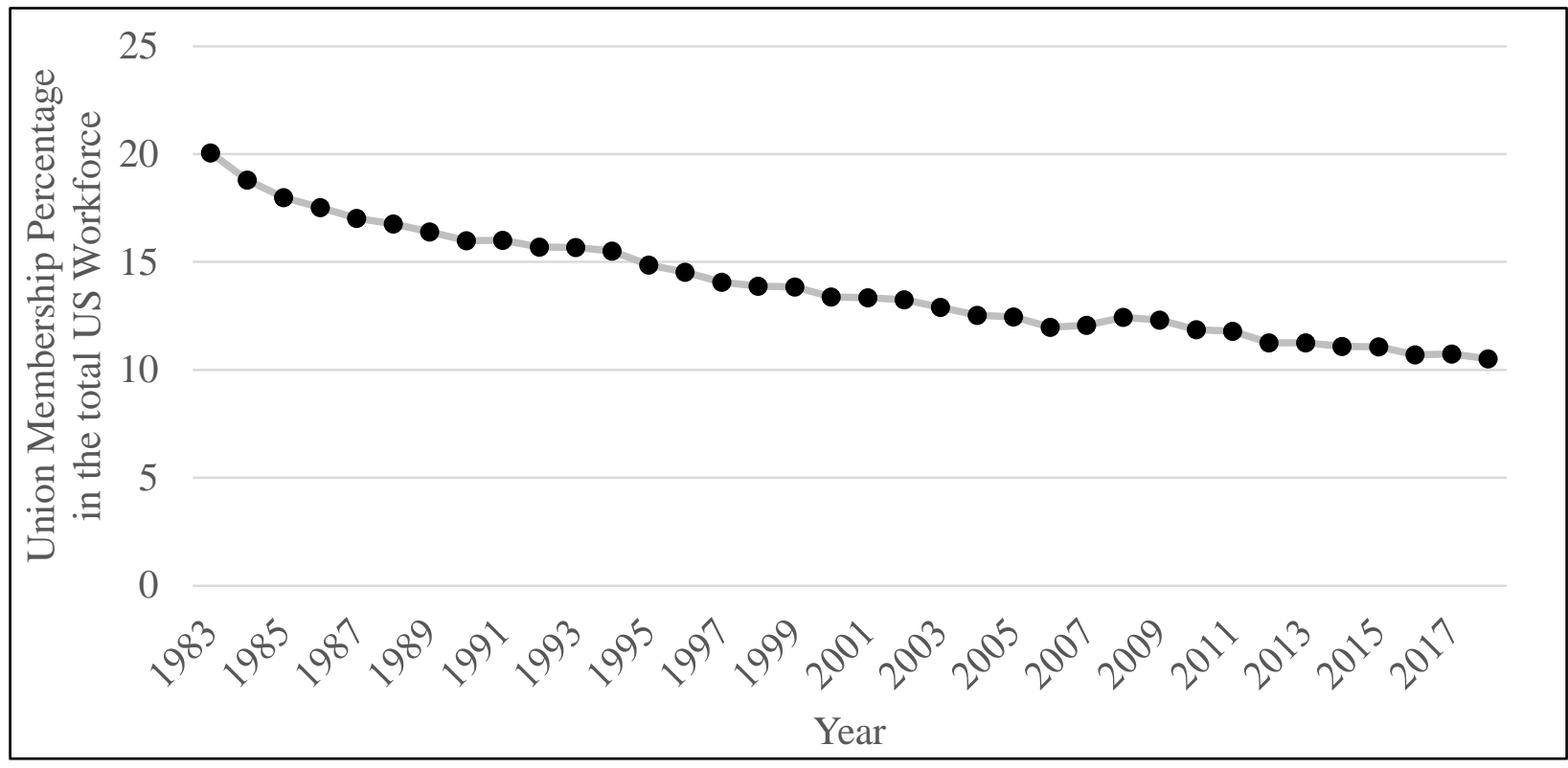

Figure 1. The decline of collective power, indexed by union membership as a function of the total labor force including part-time and full-time workers in the public and private sectors, from 
1983 to 2018. Statistics for the total workforce and union membership were calculated based on data collected by the Bureau of Labor and Statistics, a division of the US government.

\subsection{Misunderstandings of Power: Power and Prosociality}

Debates surrounding links between power and prosociality further highlight the need for a fully embedded structural and historical analysis. Studies have suggested that powerful people tend to behave more prosocially (42), or more selfishly (43), or both depending on the context and goals of the situation or the traits of the individuals who attain power (44-46). But that analysis tends to rely on personalized forms of power measured through proxies (e.g., income), manipulations of power where people imagine having (lacking) it, or operationalizations of prosociality (e.g., one-off giving to a stranger) that are limited in how they can be interpreted in the context of sociohistorical power structures.

But the historical record of societal power structures is far less mixed than our empirical record, at least in the capitalist context of North America. Across history, people tend to use power for the consolidation of power rather than for prosocial means (13, 28, 47-48). These consolidation tactics include subtle patterns of within group resource sharing among the powerful (48-49), the consistent and systematic mistreatment of the health and safety of workers (12), particularly workers of color domestically or through colonialism (50), and the undermining of democratic processes through monied interests $(47,51)$. Power, with few exceptions across history, has been used in the service of consolidating wealth and opportunities in the hands of the few and forcing people from traditionally low status groups to the margins $(13,52)$. Studies of power and prosocial behavior conducted in laboratory settings or with 
decontextualized measures and manipulations of power could benefit from interpretations that take into account this larger context.

A psychological science of power that is embedded in societal structures has tremendous capacity to inform lay people about the complexities of power, opportunity, and equity in society. Empirical work on people’s understandings of society suggest that Americans overestimate equality $(53,54)$, educational and economic mobility $(55,56)$, and progress toward racial equality $\left(57,58^{* *}\right)$ by wide margins. These systematic misperceptions are at least partially derived from a naiveté (or willful ignorance) surrounding how power is typically wielded in society and across history (13). A psychological science of power embedded in societal structures could improve lay conceptions of how power is organized along lines of race, gender, and social class because it would focus on the ways in which relationships between the powerful and the relatively powerless unfold over time, often to the benefit of the powerful (47). A structural and historical conception of power would appropriately highlight the significant challenges to prosocial uses of power faced by people in those positions, allow individuals to calibrate to the inconsistent pace of societal progress toward equity and justice, and anticipate the need for collective power and organizing.

\subsection{Toward a Structural and Historical Psychology of Power}

As we look ahead to a psychology of power for the $21^{\text {st }}$ century, we see greater opportunity for advancement if the science begins to embed personal power within broader societal structures. Contextualizing will allow researchers to understand power as it is experienced in the world, as a psychological process that is grounded in the institutions, identities, and group dynamics through which much of human behavior is experienced. 
This $21^{\text {st }}$ century study of psychological power we are envisioning will require more constraints on generality in discussions of the implications of lab-based findings (59).

Researchers will need to explicitly state the ways in which this particular analysis of power is constrained to these samples, methods, and cultural and structural contexts $\left(23^{*}, 60\right)$. Reminders of constraints on generality can also serve as a means for charting new directions in research on power by articulating testable predictions about the populations and social contexts that might moderate associations between power and behavior.

This $21^{\text {st }}$ century psychology of power will require descriptive work on the everyday experience of power within populations that vary in their social location within societal structures (61). Sampling will be a key dimension of this descriptive work because, up to this point, the psychology of power has focused primarily on data collected from online crowdsourced platforms or university students - an embedded study of power will involve descriptive work across societal structures.

Finally, this $21^{\text {st }}$ century psychology of power must move outside of the academy and the laboratory. Paradigms that rely on decontextualized games that heighten or diminish felt personal power must be paired with studies that are conducted in the field, and critically, must include more collective forms of organizing. How do our paradigms translate into these spaces and what boundaries arise from these comparisons? A $21^{\text {st }}$ century study of power is poised to better understand and link up psychological experiences of power with the structural barriers that define it.

\subsection{Conclusion}

All people are not equally able to envision a moment where they have had or will have personal power over others, and that moment is certainly likely to be embedded in the prevailing 
institutions and historical structures that define power in society and necessitate collective struggle against such structures. Here we contend that the psychological science of power must move towards greater historical and structural embeddedness. This embedding holds with it a number of challenges that include constraints on generality, more diverse study samples, and a movement toward greater field and less laboratory or online research.

However the promise of a fully historical and structural conception of psychological power far outweighs these challenges: This conception of power is poised to more clearly define who is likely to benefit from power, desire it, and attain it in the context of everyday life. And from this fully embedded conception of power we can see more clearly how progress toward greater opportunity and reduced inequality requires the consistent and collective struggle against structures of power and the people who wield that power in the service of the status quo. 


\section{References}

1. Galinsky, A. D., Gruenfeld, D. H., \& Magee, J. C. (2003). From power to action. Journal of personality and social psychology, 85(3), 453.

2. Rucker, D. D., Galinsky, A. D., \& Magee, J. C. (2018). The Agentic-Communal Model of Advantage and Disadvantage: How Inequality Produces Similarities in the Psychology of Power, Social Class, Gender, and Race. In Advances in Experimental Social Psychology (Vol. 58, pp. 71-125). Academic Press.

3. Schaerer, M., Lee, A. J., Galinsky, A. D., Thau, S., Schaerer, M., Lee, A. J., ... \& Thau, S. (2018). Contextualizing social power research within organizational behavior. The self at work: Fundamental theory and research, 194-221.

4. Du Bois, W. E. B. (1998). Black Reconstruction in America, 1860-1880. 1935. New York: Free, 38-47.

5. Jack, A. A. (2019). The Privileged Poor: How Elite Colleges Are Failing Disadvantaged Students. Harvard University Press.

6. Kraus, M. W., Park, J. W., \& Tan, J. J. (2017). Signs of social class: The experience of economic inequality in everyday life. Perspectives on Psychological Science, 12(3), 422435.

7. Payne, K. (2017). The broken ladder: How inequality affects the way we think, live, and die. Penguin.

8. **Richeson, J. A., \& Sommers, S. R. (2016). Toward a social psychology of race and race relations for the twenty-first century. Annual review of psychology, 67, 439-463.

In this review article, the authors integrate work across disciplines in psychology and connect them to a contextual and structural approach that they hope will define a new psychological approach to studying race relations in the United States. The authors also point to the ways in 
which power, and access to power for historically marginalized groups, shapes the ways in which people are able to act on their individual psychological motives.

9. Rivera, L. A. (2016). Pedigree: How elite students get elite jobs. Princeton University Press.

10. Anderson, C., John, O. P., \& Keltner, D. (2012). The personal sense of power. Journal of personality, 80(2), 313-344.

11. Chen, S., Lee-Chai, A. Y., \& Bargh, J. A. (2001). Relationship orientation as a moderator of the effects of social power. Journal of personality and social psychology, 80(2), 173.

12. Marx, K. (1992). Capital: Volume 1: A Critique of Political Economy (Penguin Classics).

13. Kraus, M., Onyeador, I. N., Daumeyer, N., Rucker, J., \& Richeson, J. (2019). The Misperception of Racial Economic Inequality.

14. **Ray, V. (2019). A Theory of Racialized Organizations. American Sociological Review, 84(1), 26-53.

In this paper, the author pulls from organizational theory and critical race theory to develop a theory of racialized organizations. In it, the author argues that racial inequality exists in and of organizations and that organizations themselves are racial structures connecting organizational rules to social and material resources in ways that privilege Whiteness.

15. Bohns, V. K., \& Newark, D. A. (2019). Power and perceived influence: I caused your behavior, but I'm not responsible for it. Social and Personality Psychology Compass, 13(1), e12427.

16. Fiske, S. T. (2018). Controlling other people: The impact of power on stereotyping. In Social cognition (pp. 101-115). Routledge. 
17. Piff, P. K., Kraus, M. W., \& Keltner, D. (2018). Unpacking the inequality paradox: The psychological roots of inequality and social class. In Advances in Experimental Social Psychology(Vol. 57, pp. 53-124). Academic Press.

18. Rucker, D. D., \& Galinsky, A. D. (2016). The agentic-communal model of power: Implications for consumer behavior. Current Opinion in Psychology, 10, 1-5.

19. Sherman, G.D. et al., (2012). Leadership is associated with lower levels of stress. Proceedings of the National Academy of Sciences, 109(44), 17903-17907.

20. Marmot, M. (2015). The health gap: the challenge of an unequal world. The Lancet, 386(10011), 2442-2444.

21. Smith, P. K., \& Hofmann, W. (2016). Power in everyday life. Proceedings of the National Academy of Sciences, 113(36), 10043-10048.

22. Smith, P. K., \& Trope, Y. (2006). You focus on the forest when you're in charge of the trees: power priming and abstract information processing. Journal of personality and social psychology, 90(4), 578.

23. *Anicich, E. M., Swaab, R. I., \& Galinsky, A. D. (2015). Hierarchical cultural values predict success and mortality in high-stakes teams. Proceedings of the National Academy of Sciences, 112(5), 1338-1343.

This paper discusses how inequalities in power can be both beneficial and detrimental for group processes. Using an extensive dataset of Himalayan mountain climbers, they find that expeditions from more hierarchical countries were more likely to complete their summit, but also suffered more fatalities along the way. 
24. Halevy, N., Y. Chou, E., \& D. Galinsky, A. (2011). A functional model of hierarchy: Why, how, and when vertical differentiation enhances group performance. Organizational Psychology Review, 1(1), 32-52.

25. Bullock, H. E., \& Reppond, H. A. (2018). Of 'takers' and 'makers': A social psychological analysis of class and classism. The Oxford handbook of social psychology and social justice, 223.

26. Kteily, N. S., \& Richeson, J. A. (2016). Perceiving the world through hierarchy-shaped glasses: On the need to embed social identity effects on perception within the broader context of intergroup hierarchy. Psychological Inquiry, 27(4), 327-334.

27. Pratto, F., Sidanius, J., Stallworth, L. M., \& Malle, B. F. (1994). Social dominance orientation: A personality variable predicting social and political attitudes. Journal of personality and social psychology, 67(4), 741.

28. Sidanius, J., Cotterill, S., Sheehy-Skeffington, J., Kteily, N., \& Carvacho, H. (2016). Social dominance theory: Explorations in the psychology of oppression. The Cambridge handbook of the psychology of prejudice, 149-187.

29. *Laurin, K., Engstrom, H. R., \& Alic, A. (2019). Motivational Accounts of the Vicious Cycle of Social Status: An Integrative Framework Using the United States as a Case Study. Perspectives on Psychological Science, 14(2), 107-137.

This paper focuses on a motivational account for the reproduction of inequality in the United States. In it, the authors review the structural factors that account for both a lack of motivation and lack of ability to achieve power among low-SES individuals.

30. *Belmi, P., \& Laurin, K. (2016). Who wants to get to the top? Class and lay theories about power. Journal of personality and social psychology, 111(4), 505. 
In this paper, the authors investigate how social class influences who is motivated to seek positions of power. Specifically, they find that individuals with lower class are less likely to desire to gain power through political means and are more motivated to seek power when they can see pathways to do so through prestige-related means and in ways that are more in line with their more culturally interdependent motives.

31. Carter, A. B., \& Phillips, K. W. (2017). The double-edged sword of diversity: Toward a dual pathway model. Social and Personality Psychology Compass, 11(5), e12313.

32. Kang, S. K., DeCelles, K. A., Tilcsik, A., \& Jun, S. (2016). Whitened resumes: Race and self-presentation in the labor market. Administrative Science Quarterly, 61(3), 469-502.

33. Redhead, D. J., Cheng, J. T., Driver, C., Foulsham, T., \& O'Gorman, R. (2018). On the dynamics of social hierarchy: A longitudinal investigation of the rise and fall of prestige, dominance, and social rank in naturalistic task groups. Evolution and Human Behavior.

34. Teele, D. L., Kalla, J., \& Rosenbluth, F. (2018). The Ties That Double Bind: Social Roles and Women's Underrepresentation in Politics. American Political Science Review, 112(3), 525-541.

35. **Craig, M. A., Rucker, J. M., \& Richeson, J. A. (2018). The pitfalls and promise of increasing racial diversity: Threat, contact, and race relations in the 21st century. Current Directions in Psychological Science, 27(3), 188-193.

This paper details a model through which actual or perceived increases in racial minorities' power in the United States leads to negative intergroup processes, such as increased prejudice. Importantly, the authors spell out some of the important contextual moderators that may exacerbate or attenuate this process (e.g., economic conditions). 
36. Williams, M. J., Gruenfeld, D. H., \& Guillory, L. E. (2017). Sexual aggression when power is new: Effects of acute high power on chronically low-power individuals. Journal of personality and social psychology, 112(2), 201.

37. Chetty, R., Friedman, J. N., Saez, E., Turner, N., \& Yagan, D. (2017). Mobility report cards: The role of colleges in intergenerational mobility (No. w23618). national bureau of economic research.

38. Kraus, M. W., Chen, S., \& Keltner, D. (2011). The power to be me: Power elevates selfconcept consistency and authenticity. Journal of Experimental Social Psychology, 47(5), 974-980.

39. Ahlquist, J. S. (2017). Labor unions, political representation, and economic inequality. Annual Review of Political Science, 20, 409-432.

40. Burawoy, M. (2008). The public turn: From labor process to labor movement. Work and Occupations, 35(4), 371-387.

41. Kim, J. Y., Fitzsimons, G. M., \& Kay, A. C. (2018). Lean in messages increase attributions of women’s responsibility for gender inequality. Journal of personality and social psychology, 115(6), 974.

42. Piff, P. K., Kraus, M. W., Côté, S., Cheng, B. H., \& Keltner, D. (2010). Having less, giving more: the influence of social class on prosocial behavior. Journal of personality and social psychology, 99(5), 771.

43. Korndörfer, M., Egloff, B., \& Schmukle, S. C. (2015). A large scale test of the effect of social class on prosocial behavior. PloS one, 10(7), e0133193. 
44. DeCelles, K. A., DeRue, D. S., Margolis, J. D., \& Ceranic, T. L. (2012). Does power corrupt or enable? When and why power facilitates self-interested behavior. Journal of applied psychology, 97(3), 681.

45. Côté, S., House, J., \& Willer, R. (2015). High economic inequality leads higher-income individuals to be less generous. Proceedings of the National Academy of Sciences, 112(52), 15838-15843.

46. Dubois, D., Rucker, D. D., \& Galinsky, A. D. (2015). Social class, power, and selfishness: When and why upper and lower class individuals behave unethically. Journal of personality and social psychology, 108(3), 436.

47. Domhoff, G. W. (2017). The power elite and the state. Routledge.

48. Nishi, A., Shirado, H., Rand, D. G., \& Christakis, N. A. (2015). Inequality and visibility of wealth in experimental social networks. Nature, 526(7573), 426.

49. Côté, S., Kraus, M. W., Carpenter, N. C., Piff, P. K., Beermann, U., \& Keltner, D. (2017). Social affiliation in same-class and cross-class interactions. Journal of Experimental Psychology: General, 146(2), 269.

50. Fanon, F. (2007). The wretched of the earth. Grove/Atlantic, Inc..

51. Kraus, M. W., \& Callaghan, B. (2014). Noblesse oblige? Social status and economic inequality maintenance among politicians. PloS one, 9(1), e85293.

52. Jost, J. T. (2017). Working class conservatism: A system justification perspective. Current opinion in psychology, 18, 73-78.

53. Norton, M. I., \& Ariely, D. (2011). Building a better America-One wealth quintile at a time. Perspectives on psychological science, 6(1), 9-12. 
54. Kiatpongsan, S., \& Norton, M. I. (2014). How much (more) should CEOs make? A universal desire for more equal pay. Perspectives on Psychological Science, 9(6), 587-593.

55. Kraus, M. W., \& Tan, J. J. (2015). Americans overestimate social class mobility. Journal of Experimental Social Psychology, 58, 101-111.

56. Davidai, S., \& Gilovich, T. (2015). Building a more mobile America-One income quintile at a time. Perspectives on Psychological Science, 10(1), 60-71.

57. Kraus, M. W., Rucker, J. M., \& Richeson, J. A. (2017). Americans misperceive racial economic equality. Proceedings of the National Academy of Sciences, 114(39), 1032410331.

58. **Ray, V., \& Seamster, L. (2016). Rethinking racial progress: a response to Wimmer. Ethnic and Racial Studies, 39(8), 1361-1369.

In this paper, the authors interrogate the idea of racial progress narratives, specifically with regards to reproducing racial hierarchy and inequality. The authors make use of a settler-colonial framework to argue that race-relations, racial hierarchy and racial progress must be analyzed through a lens of power and distribution of resources.

59. Simons, D. J., Shoda, Y., \& Lindsay, D. S. (2017). Constraints on generality (COG): A proposed addition to all empirical papers. Perspectives on Psychological Science, 12(6), 1123-1128.

60. Torelli, C. J., \& Shavitt, S. (2011). The impact of power on information processing depends on cultural orientation. Journal of Experimental Social Psychology, 47(5), 959-967.

61. Roscigno, V. J. (2011). Power, Revisited. Social Forces, 90(2), 349-374. 